\title{
Studies on avian diversity of banda university of agriculture and technology campus, Banda, Uttar pradesh, India
}

\begin{abstract}
We investigated avian diversity at the Banda University of Agriculture and Technology (BUAT), Banda, Uttar Pradesh through line transect and point count methods. Opportunistic observations were made (August, 2017 to March, 2018) and checklist of birds was prepared. BUAT falls in the semi-arid biogeographic zone of India and represents mosaic of tropical thorn forest, open scrub, agriculture farms and urbanized type of habitats. We recorded 61 bird species belonging to 15 orders and 31 families covering an area of about 383.64 hectares of the campus. Passeriformes was recorded as most dominant order with 27 species. Seven groups $(n=61)$ were formed according to their feeding habits: insectivores birds $(36 \%)$ were the most dominating group followed by omnivores $(19 \%)$, frugivores $(16 \%)$, granivores $(13 \%)$, carnivores $(12 \%)$, piscivores $(2 \%)$ and nectarivores $(2 \%)$. Out of 61 bird species, 58 species were resident, two were winter migratory (painted stork) and one was breeding migratory (jacobin kukoo). Our study indicated that Indian robin, laughing dove, rock pigeon, black drongo, green bee-eater, black kite, red and silver munia were amongst the most common species and UP State Bird sarus crane nesting was also noted during the study period. Our study revealed more vulnerable white rumped vulture and winter migrant painted stork in the BUAT campus. This study is first of a kind attempt to prepare a checklist of birds at the BUAT campus and recorded a representative sample size of the BUAT avian diversity.
\end{abstract}

Keywords: avian diversity, university campus, habitat, feeding habit, resident birds, migratory birds
Volume 3 Issue 2 - 2018

\author{
Kaushal Singh,' Aishwarya Maheshwari,' \\ Dwivedi SV ${ }^{2}$ \\ 'College of Forestry, Banda University of Agriculture and \\ Technology, India \\ ${ }^{2}$ College of Horticulture, Banda University of Agriculture and \\ Technology, India
}

Correspondence: Kaushal Singh, College of Forestry, Banda University of Agriculture and Technology, Banda, 21000I, UP, India, Email kaushalafri@gmail.com

Received: December 0I, 2017 | Published: April 26, 2018

\section{Introduction}

Diversity mostly used as an indicator of stable and sustainable ecological system. Avian diversity plays an important role in the linking of food chain in ecological unit of nature. ${ }^{1}$ Birds may give clues about overall natural health of an ecosystem. The community of birds is affected by changes in vegetation type due to natural or human induced disturbances that impact ecological resilience and recovery of a system. The relative values of different habitats can be assessed by investigating the diversity of birds of those sites. ${ }^{2}$ In present time avian diversity has been decreasing due to destruction of habitat and human induced disturbances. Random destruction of natural habitats by cutting nesting trees and foraging plants for commercial use of woods and lands are the main factor responsible for narrow down in avian foraging habitat and their nesting sites. Preparing of a list of species is basic to the study of avian species of a site, because a list indicates species diversity. Many studies have been published on avian diversity in protected areas and other natural habitats; there is lack of such studies from the campuses of various universities. Particularly in Bundelkhand region, the study on avian diversity has not been conducted. Therefore this study was conducted on avian diversity of Banda University of Agriculture and Technology (BUAT) campus, Banda and efforts have also been made to prepare a checklist of its avian species.

\section{Material and methods}

Study area: The campus of BUAT is located on Mahoba-Fatehpur road National Highway ( $\mathrm{NH} 335$ ) at Banda, between 24.53' and $25^{\circ} 55^{\prime} \mathrm{N}$ latitude and $80^{\circ} 07^{\prime}$ and $81^{\circ} 34^{\prime}$ E longitude covering an area of 383.64hectares. The university campus (Figure 1) is surrounded by village Mawai Bujurg in north, NH 335 in east and open agriculture land in west and south direction. The university campus includes the administrative block, buildings of different colleges, hostels, residential quarters, ponds, agriculture farms, roadside trees tropical dry deciduous/ thorn forest comprising Prosopis juliflora, Acacia nilotica, Azadirachta indica and Dalbergia sissoo, open scrub comprising Dicanthium, Themeda, Aristida and Heteropogon grasses with scattered trees of Acacia nilotica and shrub species Capparis decidua, in agriculture farms Cajanus cajan, Vigna radiata and V. mungo crops were recorded. In roadside plantation Delonix regia, Heterophragma adenophyllum, A. indica and Alastonia scholaris were planted. Some tree species like Feronia lemonia, Cordia mixa and Holoptelia integrifolia were observed in scattered form in whole university in very low density. A rare climber species of Zizyphus oenoplea was also recorded in P. juliflora dominated area in university campus.

Methodology: The species of birds were counted by using direct count method from walking within the university campus. Nikon $34 \mathrm{X}$ digital zoom camera was used for photography and closed observations. Line transects and point count methods were used for this study. Standard literature on Indian Birds by $\mathrm{Ali}^{3}$ and Birds of the Indian subcontinents by Grimmett et $\mathrm{al} .{ }^{4}$ were used for correct identification of birds. The study was carried out from 1st August 2017 to 30 th November 2017 . The bird species survey was conducted every day in early morning from 6.30 am to 8.30 am and on every Saturday and Sunday from 7.30 am to 9.30 am and $4.00 \mathrm{pm}$ to 6.00 $\mathrm{pm}$. Bird species that were nesting and sitting over it, were; Birds 
passing by were not recorded. The birds were also classified in-to seven categories on the basis of their feeding habit such as frugivores, carnivores, insectivores, granivores, piscivores, omnivores and nectarivores

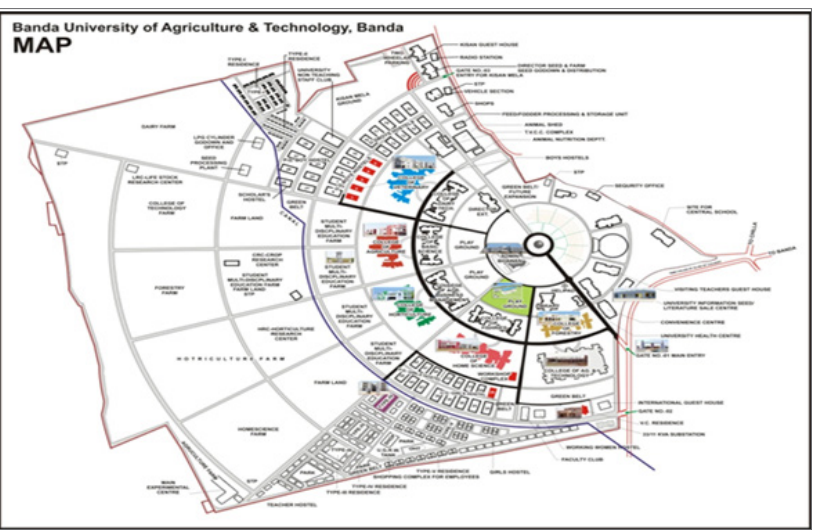

Figure I Map of Banda University of Agriculture and Technology, Banda, Uttar Pradesh, India.

Table I Checklist of avian species found in BUAT Campus, Banda, India

\section{Results and discussion}

A total of sixty one avian species belonging to fifteen orders and thirty seven families were recorded in this study, which showed seven types of feeding habit (Table 1). The maximum abundance was recorded from order Passeriformes with 44.3 percent of total avian species and represented by twenty seven species belonging to sixteen families. The maximum species richness of avian species was recorded from family Sturnidae with four species of order Passeriformes in the campus followed by order Accipitriformes Coraciiformes and Pelecaniiformes respectively (Figure 2). Residential status showed that 58 species were resident, two species (spotted redshank and painted stork) were winter migrant and one (Jacobin cuckoo) was breeding migrant. Dietary habit of avian species showed that insectivores $(36 \%)$ bird community was most dominating followed by omnivores $(19 \%)$, frugivores, granovores, carnivores, piscivores and nectarivores respectively (Figure 3). This type of pattern was also observed in other studies conducted by Dapke et al. ${ }^{5}$ in Laxminarayan Institute of Technology campus, Nagpur, India; Dey et al. ${ }^{6}$ in Maharaja Bir Bikram college, Tripura, India; Lila et al. ${ }^{7}$ Dharwad, Karnataka, India and Wadatkar (2001) in Amravati university campus, Amravati, Maharashtra, India.

\begin{tabular}{|c|c|c|c|c|c|c|}
\hline $\mathbf{S N}$ & Order & Family & Common name & Scientific name & Status & $\begin{array}{l}\text { Feeding } \\
\text { habit }\end{array}$ \\
\hline \multirow{4}{*}{ I } & \multirow{4}{*}{ Accipitriformes } & \multirow{4}{*}{ Accipitridae } & Black shoulder kite & Elanus leucurus & $\mathrm{R}$ & C \\
\hline & & & White rumped vulture & Gyps bengalensis & $\mathrm{R}$ & C \\
\hline & & & Black kite & Mulvus migrans & $\mathrm{R}$ & C \\
\hline & & & Egyptian vulture & Neophron percnopterus & $\mathrm{R}$ & C \\
\hline \multirow[t]{2}{*}{2} & \multirow[t]{2}{*}{ Bucerotiformes } & Upupidae & Common hoopoe & Upupa epops & $\mathrm{R}$ & I \\
\hline & & Jacanidae & Bronze-winged Jacana & Metopidius indicus & $\mathrm{R}$ & I \\
\hline \multirow[t]{2}{*}{3} & \multirow[t]{2}{*}{ Charadriiformes } & Recurvirostridae & Black wing stilt & Himantopus himantopus & $\mathrm{R}$ & $\mathrm{P}, \mathrm{I}$ \\
\hline & & Scolopacidae & Spotted redshank & Tringa erythropus & WM & I \\
\hline \multirow[t]{2}{*}{4} & \multirow[t]{2}{*}{ Ciconiiformes } & \multirow[t]{2}{*}{ Ciconiidae } & Painted stork & Mycteria leucocephala & WM & $\mathrm{P}, \mathrm{I}$ \\
\hline & & & Rock pigeon & Columba livia & $\mathrm{R}$ & G \\
\hline \multirow[t]{3}{*}{5} & \multirow[t]{2}{*}{ Columbiformes } & \multirow[t]{2}{*}{ Columbidae } & Collar dove & Streptopelia decaocto & $\mathrm{R}$ & $\mathrm{G}, \mathrm{F}$ \\
\hline & & & Laughing dove & Streptopelia seneglensis & $\mathrm{R}$ & $\mathrm{G}, \mathrm{F}$ \\
\hline & \multirow{5}{*}{ Coraciiformes } & Alcedinidae & White throated kingfisher & Halcyon smyrensis & $\mathrm{R}$ & $\mathrm{P}, \mathrm{I}$ \\
\hline \multirow{4}{*}{6} & & Apodidae & House swift & Apus affinis & $\mathrm{R}$ & I \\
\hline & & Coraciidae & Indian roller & Coracias bengalensis & $\mathrm{R}$ & I \\
\hline & & Meropidae & Green bee eater & Meriops orientalis & $\mathrm{R}$ & I \\
\hline & & & Greater coucal & Centropus sinensis & $\mathrm{R}$ & $\mathrm{F}, \mathrm{I}$ \\
\hline \multirow[t]{3}{*}{7} & \multirow[t]{3}{*}{ Cuculiformes } & \multirow[t]{3}{*}{ Cuculidae } & Asian koel & Eudynamys scolopaceus & $\mathrm{R}$ & $\mathrm{F}, \mathrm{I}$ \\
\hline & & & Jacobin cuckoo & Clamator jacobinus & BM & $\mathrm{F}, \mathrm{I}$ \\
\hline & & & Grey francolin & Francolinus pondicerianus & $\mathrm{R}$ & $\mathrm{G}, \mathrm{I}$ \\
\hline \multirow[t]{2}{*}{8} & \multirow[t]{2}{*}{ Galliformes } & \multirow[t]{2}{*}{ Phasianidae } & Common quail & Coturnix coturnix & $\mathrm{R}$ & G,I \\
\hline & & & Indian peafowl & Pavo crastatus & $\mathrm{R}$ & $\mathrm{O}$ \\
\hline 9 & Gruiformes & Gruidae & Saras crane & Grus antigone & $\mathrm{R}$ & 0 \\
\hline
\end{tabular}


Table continued...

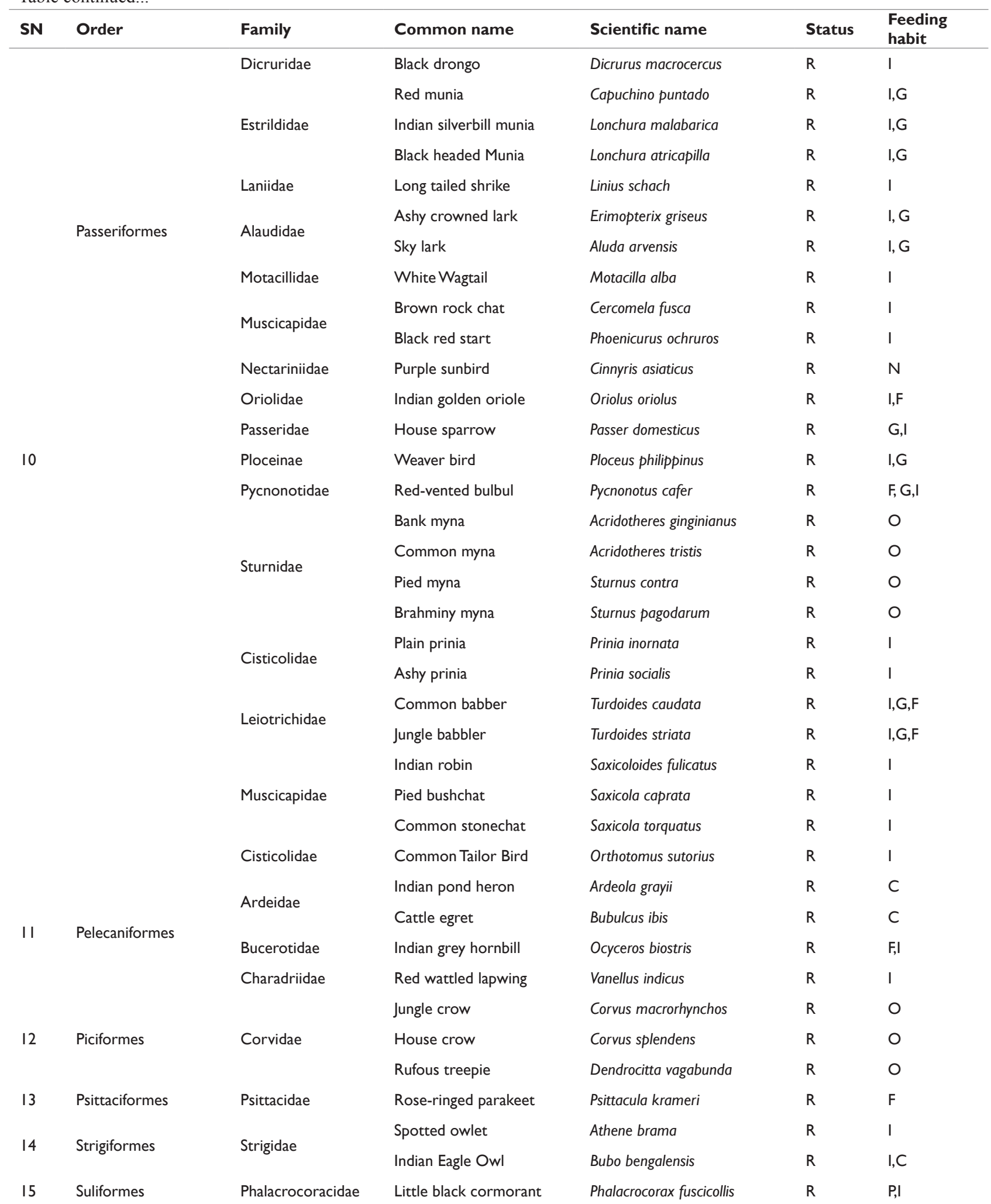

C, carnivores; G, granivores; I, insectivores; F, frugivores; O, omnivores; N, nectarivores; P, piscivores; R, resident; WN, winter migratory; BM, breeding migratory

In this study Indian robin, laughing dove, rock pigeon, black drongo, green bee-eater, black kite, red and silver munia were amongst the most common species and UP State Bird sarus crane nesting was also noted during the study period. Our study revealed more vulnerable white rumped vulture and winter migrant painted stork in the BUAT campus. The occurrence of avian species appeared to be associated with the vegetation patterns of the campus. ${ }^{8}$ The dominant tree species in the university campus were Prosopis juliflora, 
Acacia nilotica, Balanytis aegyptiaca and Azadirachta indica and along roadside Delonix regia and Heterophragma adenophyllum. Tree species like Feronia lemonia, Cordia mixa and Holoptelia integrifolia were observed in scattered form in very low density. Shrub species Zizyphus nummularia was recorded in heavy fruiting condition making it very conducive condition for many birds inside the BUAT campus. Nests and their young ones of many bird species viz. Saras crane, Laughing dove, Ring dove, Silver munia, Red munia, Weaver bird, Longtailed shrike, Black tailed kite were observed during study in the university campus.

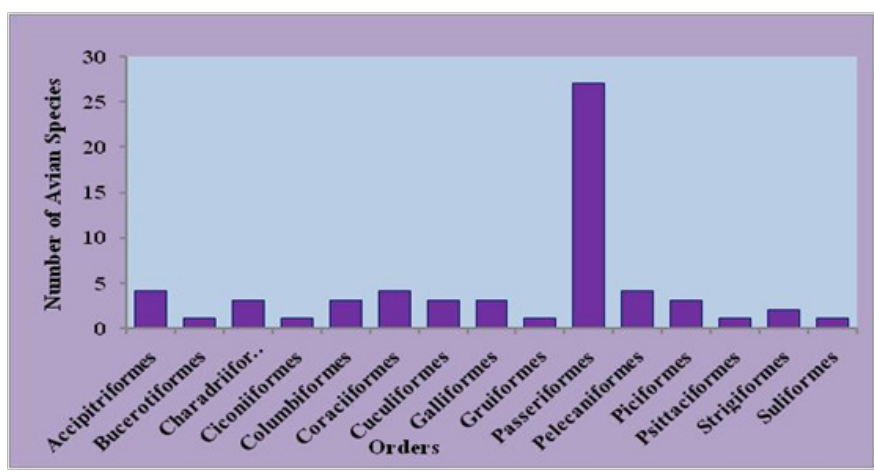

Figure 2 Order wise numbers of Avian species in BUAT campus, Banda, India.

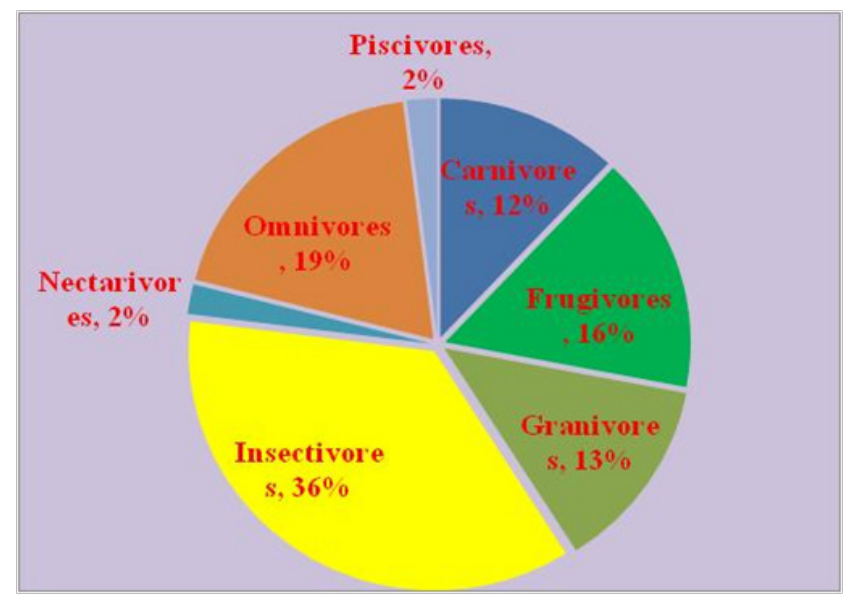

Figure 3 Dietary habits of Avian species in BUAT campus, Banda, India.

\section{Conclusion}

Rich diversity of birds is attributed to habitat structure and geographical location of the university. This area seems to provide a corridor for birds. It shows that there is a need to protect habitat structure present in university campus because it makes the food niches of bird species. In general urbanization reduced species diversity with only few species are more abundant whereas others are reduced, but in BUAT campus is not yet very homogenized and harbors rich species diversity of birds. This study brings to light the importance of open or green space of the university campus for maintaining ecological balance and conservation of avian diversity. This study is first of a kind attempt to prepare a checklist of birds at the BUAT campus and recorded a representative sample size of the BUAT avian diversity.

\section{Acknowledgements}

Authors are very thankful to Vice-Chancellor and Director, Administration and Monitoring of BUAT, Banda for having rendered facilities and encouragement during the period of study. Authors are also thankful to all the students of Hostel no 2 for their kind support during study.

\section{Conflict of interest}

Authors declare that there is no conflict of interest.

\section{References}

1. Edison PD, Abragam DA, Vijila. Terrestrial avifauna of St. John's College campus, Tirunelveli District, Tamilnadu, India. IJAR. 2016;4(1):390-395.

2. Bensizerara DH, Chenchouni AS, Bachir M, et al. Ecological status interactions for assessing bird diversity in relation to a heterogenous landscape structure. Avian Biology Research. 2013;6(1):67-77.

3. Ali S. The Book of Indian Birds. 13th ed. India: Oxford University Press; 2002.

4. Grimmet R, Inskipp C, Inskipp T. Birds of the Indian subcontinent. India: Oxford University Press; 1988.

5. Dapke S, Didolkar S, Koushik S. Studies on diversity and abundance of avifauna in and around Laxminarayan Institute of Technology, Nagpur. Journal of Entomology and Zoology Studies. 2015;3(5):141-146.

6. Dey A, Deb D, Chudhuri SD, et al. A preliminary study on avifaunal diversity of Maharaja Bir Bikram College Campus, Tripura, North East India. International Multidisciplinary Research Journal. 2013;3(2):3643.

7. Lila R, Ahamed N, Hema H, et al. Studies on avian fauna of Karnataka university campus Dharwad. Bulletin of Pure and Applied sciences. 2009;28(2):109-123.

8. Wadatkar JS. Checklist of birds from Amravati University Campus, Maharashtra. Zoos Print Journal. 2001;16(5):497-499. 